\title{
O PARADIGMA DIALÓGICO NO PENSAMENTO OCIDENTAL SOBRE TRADUÇÃO: ORQUESTRANDO VOZES
}

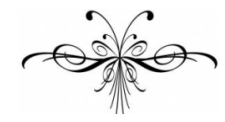 \\ LADJANE MARIA FARIAS DE SOUZA
}

Resumo

Segundo Robinson (1991), o pensamento ocidental sobre tradução compreende quatro paradigmas, representados por Agostinho, Lutero, Goethe e Buber/Bakhtin, e definidos com relação a três princípios dualismo, instrumentalismo e perfeccionismo. Os três primeiros paradigmas já estariam plenamente estabelecidos e o quarto, que o autor chama de "dialógico", estaria em desenvolvimento. Com o objetivo de contribuir para a discussão sobre a perspectiva dialógica dentro dos estudos da tradução, este artigo adota o mapeamento proposto por Robinson, em especial o quarto paradigma, a fim de nele situar a visão de autores como Pym (2002, 2006), Oittinen (2000) e Kumar e Malshe (2005). O texto aponta algumas lacunas na "perspectiva dialógica" destes autores e propõe uma reflexão sobre o texto traduzido baseada nos tipos de discurso teorizados por Bakhtin.

Palavras-chave: Estudos da tradução, paradigma dialógico, Bakhtin, filosofia do diálogo.

\begin{abstract}
According to Robinson (1991), the Western theory of translation comprises four paradigms represented by Augustine, Luther, Goethe and Buber/Bakhtin, and defined in relation to three principles - dualism, instrumentalism and perfectionism. The three first paradigms would already be fully established and the fourth one, that the author calls "dialogical", would be still unfolding. Aiming at contributing to the discussion about the dialogical perspective within translation studies, this article adopts Robinson's chart, especially its fourth paradigm, in order to situate the views of authors like Pym 2002 e 2006, Oittinen 2000 e Kumar \& Malshe 2005. It then points out some gaps in the "dialogical perspective" advanced by these authors and proposes a reflection on the translated text based on Bakhtin's classification of discourse types.
\end{abstract}

Keywords: Translation studies, dialogical paradigm, Bakhtin, philosophy of dialogue. 
$\mathrm{E}$ m seu livro “The Translator's Turn”, Robinson (1991) propõe a existência de três paradigmas já plenamente estabelecidos no pensamento ocidental sobre tradução, representados por Agostinho, Lutero e Goethe, e definidos com relação a três princípios dualismo, instrumentalismo e perfeccionismo. O autor defende também a idéia de que um quarto paradigma, que ele chama de "dialógico", estaria a se desenvolver e usa para representá-lo as figuras de Martin Buber e Mikhail Bakhtin (cf., Robinson, 1991, p. 66).

\subsection{Os três primeiros paradigmas}

Para representar o primeiro paradigma, Robinson toma as idéias de Agostinho expressas em Confissões e Da doutrina Cristã e que se resumem em três princípios - o dualismo, o instrumentalismo e o perfeccionismo. Segundo ele, a visão dualista originou-se com os gregos (Platão), foi retomada por Paulo na formulação da teologia cristã e herdada por Agostinho (Robinson, 1991, p. 38). Agostinho enfatiza "a benção do espírito e a maldição do corpo"1 (ibid.), fazendo um paralelo com o par 'significado' x 'palavra' - "a letra, o corpo, não é boa, então jogue-a fora; o espírito, o significado, (...) é bom” (id., p. 46). “O pensamento ("cogitatio") é para a palavra falada ("locutio") como a palavra espiritual de Deus para o corpo carnal do Cristo: como o que é permanente é para seu veículo ou recipiente temporário" (ibid.). Dado o interesse predominante pela tradução da Bíblia, a tradução é vista como sendo nada mais nada menos do que uma 'conversão' - o objetivo por trás do ato de traduzir é o de "auxiliar Deus (concebido como a instância Máxima da Escrita na língua-fonte) a converter o leitor da língua-alvo (...)” (id., p. 210). Um dos princípios-chave do dualismo "Platônico/Paulino/Agostiniano" é aquele que separa tudo o que existe numa hierarquia de instrumentalização cujo nível máximo é Deus: "os leigos são instrumentos do clero e o clero é instrumento de Deus. Os homens leigos instrumentalizam as mulheres leigas. As mulheres instrumentalizam as crianças. Os meninos instrumentalizam as meninas (...)" (id., p. 50). Dentro desta hierarquia, é claro, o tradutor é instrumentalizado pelo autor do texto-fonte, isto é, por Deus, que é a instância autoral máxima: "a tarefa do tradutor é se manter fora do caminho de modo que Deus possa fazer o seu trabalho sobre o leitor da língua-meta. Ficar entre Deus e o leitor da língua-meta, com certeza, porém invisivelmente: como um instrumento, um introvertido, uma janela (id., p. 210). O ideal Agostiniano em termos de tradução é, pois, a tradução perfeita, capaz de "substituir o original", ou seja, aquela que adquire o status de original - nela ouve-se apenas a voz do autor original. Nessa tradução ideal, todo o significado do original é resgatado, seja ele visto como o Logos, a palavra de Deus ou o Lógico, o significado

${ }^{1}$ Todas as citações de Robinson (1991) foram traduzidas do inglês pela autora. 
transcendental, o significado profundo². Segundo Robinson, "desde Agostinho e Jerônimo, a tradução é vista como um problema técnico: há certas dificuldades óbvias a serem superadas: divergências sintáticas, incompatibilidades semânticas (...) e a atenção se volta para elas (...) para 0 modo correto de proceder" (Robinson, 1991, p. 210, grifos no original).

É contra esse sistema dualista inerte, protetor e conservador do Cristianismo medieval que Lutero vai se posicionar, repensando o papel do tradutor. Em "Carta Aberta sobre a Tradução", Lutero expressa visões opostas às dos papistas "literalistas". Lutero afirma que "a tradução não é em absoluto uma arte para qualquer um” (Lutero, 1530/2006, p. 111). Segundo ele, para se traduzir, é necessário ter "arte, aplicação, razão e entendimento" (id., p. 97), além de experiência prática (cf., p. 109). Para isso, é necessário se atentar, por um lado, para o que Lutero chama a "propriedade da língua", que a distingue das demais e, por outro, para a necessidade de dar ao leitor a compreensão do texto através do uso da língua corrente - "não se deve perguntar às letras na língua latina como se deve falar alemão (...) há que se perguntar à mãe em casa, às crianças na rua, ao homem comum no mercado, e olhá-los na boca para ver como falam e depois traduzir “(id., p. 105). Segundo Lutero, a tradução literal oblitera o sentido do texto, pois viola a "propriedade da língua" para a qual se traduz e deve ser evitada se se quer traduzir com "clareza e consistência" (id., p. 103). Mas o que de fato caracteriza a mudança de paradigma trazida por Lutero é, segundo Robinson, a "libertação" do tradutor da "autoridade institucional" da Igreja (cf. Robinson, 1991, p. 1). Lutero impõe sua presença como tradutor "doutor"3, contrapondo à visão agostiniana sobre o resgate do significado transcendental, da 'Palavra de Deus', sua própria visão quanto à 'correta' interpretação do sentido do original. E, ao dar a si mesmo o lugar de 'leitor' privilegiado, ele advoga também para o leitor da tradução o direito de compartilhar de sua mesma compreensão. Daí a defesa apaixonada do uso da língua nacional do modo como é falada, respeitando a sua "propriedade".

Robinson começa a delinear uma nova mudança de paradigma a partir do West-Östilicher Divan de Goethe. É nesse texto que Goethe classifica a "tradução singela" ou simplificadora de Lutero, que "nos apresenta o estrangeiro à nossa maneira" (Robinson, 1991, p. 19), como uma primeira espécie de tradução à qual sucede uma segunda "época" (não mais "espécie") que Goethe chama de parodística "no mais puro sentido da palavra" (id., p. 21). Nela "se procura a transposição para as condições do estrangeiro, mas, na verdade, apenas para se apropriar do sentido desconhecido e constituí-lo com sentido próprio" (ibid.). Para Robinson, a mudança trazida por Goethe se

\footnotetext{
${ }^{2} \mathrm{O}$ exemplo máximo de tal tradução é a Septuaginta, a mais antiga tradução da bíblia hebraica para o grego. Segundo a tradição, ela teria sido traduzida por 72 eruditos judeus em um período de 72 dias, daí o nome (septuaginta em Latim significa 'setenta') (cf. Baker e Saldanha, 2009, p. 21).

${ }^{3}$ É assim que Lutero se refere a si mesmo em Carta Aberta sobre a Tradução (cf. Lutero, 1530/2006, p. 95).
} 
reflete no próprio uso do termo 'época' para o segundo tipo de tradução. É a mudança “da rigidez para a fluidez” (id., p. 81), i.e., a introdução do 'tempo', do dinamismo que vai abalar a estabilidade do sistema dualista introduzindo aí a dialética de Hegel - "o constante fluxo das coisas em direção a seus opostos e das novas misturas para os opostos destas, indo cada vez mais alto, até elas atingirem o estágio 'mais alto de todos e último', o paraíso, a perfeição” (id., p. 90). Esse último estágio constitui a terceira época na teoria de Goethe, "onde se procura tornar a tradução idêntica ao original” (Goethe, 1813/2001, p. 21).

Segundo Robinson "a única diferença de fato entre a primeira "espécie" e a segunda "época" de tradução definidas por Goethe parece ser que "a primeira nos familiariza com a terra estrangeira segundo o nosso próprio sentido (submissão aos hábitos de fala do leitor do texto-meta); a segunda se apropria da situação estrangeira e a representa segundo o sentido próprio do tradutor (expressão pessoal)" (Robinson, 1991, p. 83). E é esse sentido do próprio tradutor que Robinson coloca como um rompimento com o paradigma luterano: "pela primeira vez, o tradutor reivindica para si o papel de proprietário, de empreendedor, de proprietário de significados e palavras" (id., 86). Com Lutero, o tradutor deixa de ser um instrumento ou servo da instituição cristã para ser um "indivíduo" capaz de decidir sobre o "sentido". Porém, este seu sentido perde a exclusividade quando Lutero se coloca a serviço de outros cristãos não tradutores - o "meu sentido" se torna o "nosso sentido" (cf. id. p. 84). Lutero vai da "auto-afirmação para a autonegação" (id., p. 85), enquanto que os tradutores que Goethe posiciona na segunda época fazem o contrário - "eles vão da autonegação (abertura à penetração do que está fora) à auto-afirmação" (ibid.). No paradigma goethiano, a política da "conversão" em Lutero torna-se a "poética da salvação messiânica direta" (id., p. 67). Goethe se contrapõe não apenas à igreja católica, mas a todas as instituições, "todas as ideologias eclesiásticas ou científicas que ensinam homens e mulheres a serem vermes; o lado "bom" é o da centelha da imaginação" (id., p. 68). A imaginação torna o tradutor um salvador messiânico. $\mathrm{O}$ poder das palavras está não em captar e transmitir conhecimentos, mas sim em criar, o que envolve tanto a 'forma' quanto o 'sentido' (terceira época). Daí, segundo Robinson, a tradução se tornar para os românticos "um tudo ou nada, ou o significado total, a compreensão total, a total libertação da opressão, ou o fracasso total, a total intraduzibilidade" (ibid.).

\subsection{O paradigma “dialógico" - Buber e Bakhtin}

Para Robinson, o "paradigma dialógico" se caracteriza por uma superação dos princípios do dualismo, do instrumentalismo e do perfeccionismo que têm pautado o pensamento e a prática ocidentais da tradução. Para representar esse novo paradigma, o autor toma não mais um 
tradutor que teoriza sobre a tradução, mas dois filósofos - Martin Buber e Mikhail Bakhtin, este sendo, segundo Robinson, o "mais ilustre seguidor" do primeiro (cf. Robinson, 1991, p. 66). Resumidamente, a filosofia de Buber propõe que o homem tem duas atitudes distintas diante do mundo, traduzidas por duas palavras-princípio: EU-TU, representando o "encontro entre dois parceiros na reciprocidade e na confirmação mútua” e EU-ISSO, representando "a experiência e a utilização, atitude objetivante" (Vilela e Borges, 2002, p. 10-11). Para Buber,

existem vários modos diferentes de EU-TU, e o Tu pode se constituir por qualquer ser que esteja presente no face-a-face, como: homem, Deus, obra de arte, pedra, flor, peça musical. Da mesma forma, o Isso também pode ser qualquer ser que é considerado objeto de uso, de conhecimento, de experiência de um Eu. O Eu não existe sozinho, ele está sempre ligado ao Tu ou ao Isso. E neste mundo da relação temos 3 esferas: a relação com a natureza, que está aquém da linguagem; a relação com os homens, onde podemos endereçar e receber o Tu; e a relação com os seres espirituais, onde há uma linguagem silenciosa" (Vilela e Borges, 2002, p. 11).

No prefácio de sua nova tradução das Sagradas Escrituras do hebraico para o alemão, Buber critica o primeiro tipo de tradução apontado por Goethe, ou seja, a tradução do "conteúdo" como vista e praticada no paradigma luterano, contra-argumentando que "a plena revelação é sempre carne humana e voz humana, (...) esta carne e esta voz no mistério de sua singularidade temporal" (Buber, 1963: 351-2, Apud Robinson, 1991, p. 92). Em um livro anterior, Ich und Du, Buber propõe que:

O Eu da palavra-princípio Eu-Isso, o Eu que não é corporalmente confrontado por um Tu, mas que é circundado por uma multidão de "conteúdos" possui apenas passado e não presente. Em outras palavras, enquanto o ser humano lida com as coisas que experimenta e usa, ele vive no passado e seu momento não tem presença. Ele tem apenas objetos; os objetos, porém, consistem apenas em ter sido. A presença não é aquilo que se decompõe e passa, mas aquilo que nos confronta, esperando e resistindo (Apud Robinson, 1991, p. 96).

Segundo Robinson, a "concepção dialógica do Eu-Tu aponta para uma nova concepção de tradução que é (potencialmente) imensamente proveitosa” (id., p. 100). Em sua interpretação do texto de Buber,

Gegenwart, a presença corporal do Tu que nos "espreita" quando pronunciamos a palavra-princípio Eu-Tu, na tradução, é o confronto do tradutor com o texto-fonte, e, através do texto, com o autor-enquanto-Tu; e depois disso, é o confronto do tradutor com o leitor-do-texto-meta-enquanto-Tu”. Uma única vez. Todo diálogo tradutório ocorre apenas 
uma vez̧; não há repetição, visto que todo diálogo está presente apenas enquanto é presente, $e$ ele nunca volta a ser. (Robinson, 1991, p. 96).

$\mathrm{Na}$ interpretação de Robinson, é essa insistência de Buber na "singularidade temporal" da tradução, enquanto Eu-Tu, que faz com que ele permaneça atrelado à mesma visão mística dos românticos da intraduzibilidade e da conseqüente necessidade de uma "infinita aproximação a uma meta impossível" (id., p. 94). Segundo o autor, o dualismo rígido adotado por Buber em sua divisão dos dois mundos do Eu-Tu e do Eu-Isso, "perpetua a divisão entre teoria e prática, ciência e arte", uma vez que o confronto entre tradutor e autor e entre tradutor e leitor não pode ser estabilizado em um padrão sem se evocar o Eu-Isso, "que petrifica toda e qualquer presença em passado" (id., p. 96). Para ele, então, faz-se necessária uma "concepção de relação e diálogo que combine não apenas som e sentido, e não apenas Eu e Outro, mas também teoria e prática" (Robinson, 1991, p. 100), de modo que possamos não apenas viver o momento presente do confronto entre Eu e Tu, mas também falar de tal momento. E a solução proposta por Robinson se baseia no conceito de "dialogismo interno" ou "heteroglossia" proposto por Bakhtin (cf., ibid.).

Para superar o dualismo em Buber, Robinson retoma a visão bakhtiniana de que "a língua é saturada de ideologia" através das muitas vozes (heteroglossia) que a falaram (id., p. 101). Para Robinson, isso quer dizer que "o Eu-Tu que Buber idealiza como uma relação misticamente vitalizadora e quase impossível, está desde sempre já embutida na linguagem” (id., p. 103). E, segundo ele, essa visão bakhtiniana da linguagem deriva duas importantes implicações para a teoria da tradução: 1) a impossibilidade de uma equivalência objetiva:

uma vez que as palavras não pertencem, de fato, a ninguém, uma vez que elas não são "propriedade" que possa ser atribuida ou roubada ou invadida, mas flutuam livremente no dominio público, não pode existir nenbuma distinção pura, perfeita ou ideal entre textos, $e$ desse modo, nenhuma correspondência pura, perfeita ou ideal entre eles (...) Não existe nenhuma maneira de se estabelecer uma "equivalência" objetiva entre textos ou entre as respostas de receptores a eles (Robinson, 1991, p.105).

2) a inexistência de fronteiras entre as línguas: "as fronteiras entre as línguas que Buber imaginou como obstáculos intransponíveis ao sucesso da tradução, são de modo análogo, ficções provisórias mantidas socialmente e politicamente - e não verdadeiros muros" (id., p. 106).

O tradutor, ou o corpo do tradutor é, então, o lugar onde as linguas artificialmente dualizadas - Lingua-fonte e Lingua-meta - se encontram, confluem, se combinam. No ato que chamamos de "pré-tradução", a preparação somática do tradutor para a tarefa de tradução, lingua-fonte e lingua-meta são indistinguiveis" (Robinson, 1991, p. 107). 
Além disso, as línguas que o tradutor usa passam a fazer parte de sua compreensão linguística/somática (cf. p. 106) - “o que é a heteroglossia ou a polifonia de Bakhtin senão uma Babel internalizada (somatizada)?” (id., p. 106).

Para falar da superação do instrumentalismo e do perfeccionismo, Robinson utiliza também o discurso de outros teóricos, o que vai além do objetivo deste artigo. Na próxima seção, são introduzidas as vozes de outros teóricos dos Estudos da Tradução que trataram do tema "tradução e diálogo".

\section{A tradução e a "filosofia do diálogo": Laygues (2001, 2005, 2007), Pym (2007)}

Em Translation Studies and Western Philosophy, Pym (2002) passa em revista alguns teóricos da tradução que lançaram mão do discurso filosófico. Entre eles está Arnaud Laygues (2001) que se refere às idéias de Buber, Marcel e Levinas, a fim de refletir sobre a ética da tradução. Em Translation technology as rupture in the philosophy of dialogue, Pym (2006) volta a se referir a Laygues (2001, 2005, 2007), cuja reflexão agora mais completa, abrange as teorias destes três filósofos mais a de Ricoeur, no que Laygues chama de "filosofia do diálogo". Laygues fundamenta sua filosofia da tradução, que é uma "ética da cooperação humana", na visão buberiana da relação EU-TU e EU-ISSO, e, sobre essa base, ele encadeia idéias dos outros filósofos, como: 1) de Marcel, a idéia de que dialogamos com o outro "não apenas enquanto um de nós, mas como Autrui, o "outro enquanto outro"" (Pym, 2006, p. 3); 2) de Levinas, a idéia de que o outro (o não-Eu) é "uma face para com a qual nós temos certas obrigações éticas" (Pym, 2002, p. 10); e, 3) de Ricoeur, a idéia da dualidade da identidade - de um lado, "a identidade do mesmo (idem), do tipo repetitivo, em todos os níveis associada à equivalência" (Pym, 2006, p. 3) e, de outro, a identidade própria (identité ipse), continuamente construída no diálogo com o outro", que na tradução corresponderia à identidade construída através de "múltiplas decisões de tradução, e na verdade, através de múltiplas traduções" (ibid.) A partir desse conjunto de idéias, Laygues defende que "os tradutores deveriam buscar as relações humanas por trás dos textos, os leitores por trás do cliente, o interpessoal por trás do objetivo. Ao invés de trabalhar com a língua enquanto um conjunto de coisas, nós deveríamos trabalhar com pessoas enquanto expressas através da língua" (Pym, 2006, p. 2).

Pym (2006) aponta como herdeiros dessa "filosofia do diálogo" autores como Berman (1999), para quem "a tarefa do tradutor é "reconhecer e receber o outro enquanto outro" (Pym, 2006, p. 3), e Kristeva (1998), que "considera uma Europa multicultural de múltiplas imigrações como uma estrutura em que a identidade é profundamente 'estrangeira para si mesma' (...) constantemente engajada com sua própria redefinição” (ibid.). 
Pym questiona a visão dialógica da tradução a partir das tecnologias de tradução e seu uso, em especial as memórias de tradução. Segundo ele, é a tecnologia que deve em última instância minar a ilusão filosófica da tradução como diálogo" (Pym, 2006, p. 4). Ele afirma que devido à mediação da tecnologia, a tradução não é um diálogo direto, nem nunca o foi (id., p. 6). O que ele quer dizer é que a tecnologia interfere no diálogo, ela não é neutra. $\mathrm{E}$ ele toma como exemplo tecnologias eletrônicas como sistemas de memória de tradução, sistemas de gerenciamento de conteúdo e de terminologia especialmente usadas em larga-escala na chamada "indústria de localização", que constitui uma grande porcentagem das traduções feitas no mundo globalizado. Tais tecnologias, que visam a maior rapidez e o menor custo no processamento de traduções, baseiam-se na memorização de informações no nível da oração e assim permitem a geração semi-automática de texto em várias línguas. Desse modo, o tradutor trabalha apenas com orações ou no máximo parágrafos (em geral sem ter acesso ao texto integral, a informações sobre o objetivo da tradução ou sobre o usuário final), permanecendo aquém de um “diálogo face-a-face com o outro" (ibid.). É por essa razão que Pym afirma que "mesmo enquanto uma frágil metáfora equivocadamente delineada, este tipo de tradução não pode servir de modelo para uma ética da comunicação entre culturas" (ibid.).

Para Pym, a "filosofia do diálogo" como proposta por Laygues, "nos mostra um tradutor conversando com um autor" (id., p. 7), e, portanto, o tradutor "se volta para o passado, para a palavra do outro em um contexto finito" (ibid.). Daí Pym questionar: "porque é que nenhum dos filósofos considera a relação do tradutor com os futuros leitores ou usuários nos mesmos termos? Porque é que a única relação ética deve ser com um autor e não com um receptor?” (ibid.). Sua posição, enquanto teórico e professor de tradução, é a de que a "ilusão do diálogo" é "pedagogicamente útil", e, enquanto tradutor, é a de que "nosso trabalho deveria ajudar no avanço de tecnologias que capacitem aqueles que trabalham com línguas a entrar em tais diálogos. Isso implica maior visibilidade dos contextos discursivos, mais informação sobre os perfis de usuários e acesso a respostas” (id., p. 8).

\section{O tradutor no diálogo da tradução - Oittinen (2000), Kumar e Malshe (2005)}

Em seu livro Translating for Children (2000), Oittinen toma alguns dos conceitos-chave da teoria de Bakhtin a fim de descrever a "conversa dialógica que produz um todo traduzido digno de sua mensagem"4 (p. 168). Baseada na noção de diálogo em Bakhtin, ela define a situação de tradução como "um processo dialógico e colaborativo que ocorre em situações particulares” (id., p. 161). As diferentes vozes que participam de tal processo são, por exemplo,

\footnotetext{
${ }^{4}$ Todas as citações de Oittinen (2000) foram traduzidas do inglês pela autora.
} 
"no diálogo da tradução para crianças, diferentes autores (inclusive autorestradutores), diferentes leitores (inclusive tradutores-leitores) e diferentes ilustradores" a partir de cujo encontro novos significados são gerados" (id., p. 161). Nesse processo, a autora destaca em primeiro lugar, o papel de leitor especial que o tradutor desempenha - "o tradutor é um tipo muito especial de leitor: ele/a compartilha sua experiência de leitura com os leitores da línguameta" (id, p. 17). Ela destaca que para Bakhtin "compreender não é decodificar uma mensagem, mas antes mesclar vários horizontes, os dos diferentes leitores e os dos diferentes escritores" (id., p. 19). Aí o tradutor não pode mais se impor a tarefa de uma leitura passiva, que busca reproduzir o "mesmo", pois, em Bakhtin "compreensão passiva não é compreensão nenhuma" (id., p. 20). Oittinen cita Bakhtin, quando ele afirma que "para entender um autor do modo mais enriquecedor, não se deve nem reduzi-lo a uma imagem de si mesmo nem fazer de si mesmo uma versão dele" (id., p. 32). No diálogo da tradução, o tradutor, enquanto leitor está em igualdade de condições com o autor (cf. id., p. 26) - como os outros leitores ele busca respostas no texto, aceita, rejeita, diz sim e não (cf. id., p. 21). O tradutor entra para um diálogo no qual a palavra derradeira ainda não foi pronunciada, ou seja, "quaisquer intenções que os autores possam ter tido, por melhor que tenham imaginado seus leitores implícitos, os leitores do futuro, inclusive os leitores das traduções, sempre lerão os livros que escreveram a partir de seus propósitos particulares, a partir de suas perspectivas particulares" (id., p. 24). Nenhum autor tem a garantia de uma perfeita compreensão por parte de seus leitores. Nesse contexto, Oittinen não faz distinção entre tradução e adaptação - "toda tradução inclui adaptação, pois, quando traduzimos, nós sempre pensamos nos nossos futuros leitores, que podem ser chamados os "supradestinatários" de nossas histórias, histórias escritas tanto pelos autores originais quanto pelos tradutores" (id., p. 164). Oittinen afirma que “(...) para ter sucesso, um tradutor deve tornar suas as palavras parcialmente alheias; a palavra numa tradução necessariamente contém também as intenções e sentimentos do tradutor" (id., p. 31). E isso, essa "relativização da autoridade do original", segundo a autora, não significa necessariamente desrespeito. Para ela, "dialogismo não significa submeter-se à autoridade do original mas acrescentar-lhe algo, enriquecê-lo, a partir do respeito, ou lealdade ao original, de modo a criar uma nova interpretação para o público da língua-meta" (id., p. 164). É por isso que, "como um dos criadores, o leitor também tem responsabilidades. Como leitor, o tradutor é responsável por sua leitura, não apenas com relação a si mesmo mas com relação a todos os participantes de cada situação dialógica” (id., p. 31).

Analogamente, Kumar e Malshe (2005) propõem que se veja a tradução como a composição de uma "reação-resposta" com relação ao texto-fonte que antecipa as respostas dos leitores do texto-meta (cf., p. 116). Para eles, isso implica que o tradutor "compreenda tanto a cultura-fonte quanto a cultura- 
meta como seu 'outro"”5 (ibid.). Assim vista, a tradução é portanto "um evento dialógico, ou seja, um acontecimento aberto e não finalizável do diálogo entre a consciência do tradutor e as culturas-fonte e meta" (ibid.).

O primeiro aspecto desse diálogo tradutório, abordado por Kumar e Malshe é a compreensão do tradutor através da leitura - "a tradução é impossível com a "compreensão passiva" uma vez que esta apaga a diferença entre o eu e o outro", ou seja, a compreensão passiva "apenas admite a existência de uma única perspectiva" (2005, p. 117). Para os autores, é a compreensão ativa que "torna a tradução uma 'reação-resposta" (ibid.). Em segundo lugar, os autores apontam a importância do conceito de 'metalingüística', como definido por Bakhtin, para o tradutor:

Em seu ensaio, 'O Problema do Texto', Bakbtin identifica dois importantes 'pólos' em um texto (1994b: 105). O primeiro pólo consiste em um sistema da lingua, ou seja, um sistema de signos que é reiterável e reproduzivivel. Muito convincentemente, Bakhtin também defende que existem elementos extralingüisticos em todo texto, que não são reiteráveis e reproduqivivis.

Este é o segundo pólo, que ele chama de dialógico. Segundo Bakhtin, os elementos extratextuais se referem ao plano e à intenção do autor, qualidades como honestidade, verdade e beleza do texto, significados contextuais e suas implicaçôes para a relação emissorreceptor, as dimensões espaciais e temporais do texto, etc. O significado não é tão dependente do sistema da língua; é antes um produto do sistema dialógico do texto, seu segundo pólo.

Uma investigação destes elementos, que extrapola os limites da lingüistica, adquire uma importância vital para Bakbtin. Ele chama tal estudo de 'metalingüistica' (1994b: 114)

(Kumar e Malshe, 2005, p. 117-118).

A questão crucial abordada pelos autores é, então, a de como traduzir o sistema dialógico com seus elementos infinalizáveis, i.e., o segundo pólo do texto. E é nos conceitos de "dialogismo interno" e de "palavra bivocal" que os autores vão encontrar respostas para os tradutores:

Como escreve Bakbtin em seu livro Problemas da Poética de Dostoiévski, "[...] um autor pode se utilizar da palavra de uma outra pessoa com intençôes próprias inserindo uma nova orientação semântica numa palavra que já tem - e mantém - a sua própria orientação ... Assim, duas orientações semânticas, duas vozes estão presentes em uma única palavra" (1984: 156-157). A palavra aqui não é a palavra do autor mas uma palavra emprestada: portanto, ela é a 'palavra do outro'. Devido à 'dialogização interna', isto é, à capacidade da

palavra de ser dialogizada a partir de seu interior, a palavra adquire uma característica dialógica especial e se torna 'bivocal' (Kumar \& Malshe, 2005, p. 119).

Kumar e Malshe acrescentam a distinção feita por Bakhtin entre a palavra bivocal passiva e a ativa, afirmando que a primeira, que permite ao

\footnotetext{
${ }^{5}$ Todas as citações de Kumar \& Malshe (2005) foram traduzidas do inglês pela autora.
} 
autor "utilizar deliberadamente as duas orientações semânticas da palavra", é de "grande interesse para o tradutor" (ibid.). Para tentar esclarecer o conceito de palavra bivocal e sua importância para o tradutor, os autores dão alguns exemplos da literatura - o uso que TS Eliot faz das palavras "Datta", "Dayadhvam", e "Damyata" dos Upanishads, o uso de palavras como "Karma" por Raja Rao e as traduções de "Bhoota" (título de um poema de Adiga) e de nomes de personagens míticos como "Gauri" e "Shyamala" em um poema de Rege. Em todos eles, os autores mostram como a conservação da palavra em sua forma original faz com que ela se torne bivocal e como a tradução em palavras da língua-meta implica uma perda semântica ao tornar os equivalentes monológicos (cf. id., p. 119-122).

\section{Bakhtin, 'saturação ideológica' e discurso bivocal ativo}

O primeiro ponto a observar, após orquestrar vozes e ecos de vozes, nesse diálogo virtual, são certas lacunas (silêncios propositais ou não). A primeira destas é a ausência de Bakhtin enquanto filósofo da linguagem na chamada "filosofia do diálogo" (Laygues, Pym). É curioso o fato de Pym ter associado Kristeva6 à "filosofia do diálogo" e não Bakhtin. A inclusão de Bakhtin dispensaria a crítica de Pym de que "todas as imagens da tradução como diálogo, todas essas filosofias do outro, nos mostram um tradutor conversando com um autor" (Pym, 2006, p. 7) e seu conseqüente questionamento sobre por que não se estabelecer uma relação ética também com o receptor. A segunda lacuna é, no discurso daqueles que incluíram Bakhtin (exceto Robinson), a falta de ênfase no caráter ideológico da língua, i.e., na idéia de que todo enunciado constitui um ponto de vista e busca convencer seu interlocutor. Robinson aponta esse caráter ideológico da língua e inclusive o coloca como a chave da teoria bakhtiniana para a superação da visão dualista e excludente em vigor desde o paradigma agostiniano, uma vez que tal caráter privilegia a inter-relação entre os dois lados do dualismo, ao invés de acentuar as barreiras entre eles (cf. Robinson, 1991, p. 101-3). Da idéia da "saturação ideológica" da língua decorre que somos todos "ativistas" num certo sentido. Robinson reconhece isso ao afirmar que:

O dialogista não pode reivindicar objetividade. O diálogo nunca pode fixar o passado no solo da perfeita descrição. É a minha palavra contra a sua, ou a dele, ou a dela, ou a de quem quer que esteja participando do diálogo. Tudo o que eu posso fazer é tentar convencer você de que eu estou certo - ou pelo menos de que sou interessante ou mereço ser lido" (Robinson, 1991, p. 69).

E é assim que ele deixa claro o seu projeto de "libertar" os tradutores da tirania dos três princípios (dualismo, instrumentalismo e perfeccionismo). Os

\footnotetext{
${ }^{6}$ Kristeva é considerada um “canal” do pensamento de Bakhtin no Ocidente (Martins, 2003).
} 
objetivos dos outros teóricos estão também expressos: “ajudar a promover tecnologias que permitam àqueles que trabalham com línguas participarem do diálogo" - Pym (2007); "aumentar o conhecimento do (...) leitor sobre a tradução através da descrição da conversa dialógica que produz um todo digno de sua mensagem" - Oittinen (2000, p. 168); e "explorar o papel que a metalingüística de Bakhtin desempenha para o tradutor", em especial a importância da 'palavra bivocal' - Kumar e Malshe (2005). Como Robinson, eles buscam compartilhar com seus leitores uma certa visão de tradução, que se pode chamar de 'perspectiva dialógica', cada um à sua maneira e com outras intenções mais específicas em vista, como, por exemplo, a de ter seu trabalho aceito para publicação, divulgado e lido e, quem sabe aplicado, o que vai além de simplesmente "descrever" e "explorar". Uma total adesão ao "paradigma dialógico" implica clareza no que diz respeito ao caráter ideológico (ativista e ao mesmo tempo contingente) de toda e qualquer visão que se proponha para qualquer objeto de estudo.

Trazendo-se a questão da ideologia para a tradução, pode-se concluir que também o texto produzido pelo tradutor, enquanto enunciado integrante do diálogo entre diferentes vozes, nunca pode ser ideologicamente neutro. A "resposta" dada pelo tradutor vai também estar impregnada de ideologia, seja sua resposta enquanto leitor, seja sua resposta enquanto escritor. No primeiro caso, como sugere Bakhtin, "a cada palavra da enunciação que estamos em processo de compreender, fazemos corresponder uma série de palavras nossas, formando uma réplica" (Bakhtin, 1981, p. 136). No segundo caso, também segundo Bakhtin, "não se pode construir uma enunciação sem modalidade apreciativa" (id., p. 137). Assim sendo, também na tradução existem duas vozes, uma que fala (o autor) e uma que avalia e responde (o tradutor). Além disso, Bakhtin acrescenta que,

por maior que seja a precisão com que é transmitido, o discurso de outrem incluído no contexto sempre está submetido a notáveis transformações de significado. O contexto que avoluma a palavra de outrem origina um fundo dialógico cuja influência pode ser muito grande" (Bakhtin, 1998, p. 141).

Ou seja, quem traduz inevitavelmente enquadra o texto, i.e., introduz nele seus acentos e suas expressões. E tal enquadramento vai depender em grande parte da atitude do tradutor face ao texto-fonte, que por sua vez depende da tarefa de tradução que lhe foi passada.

Tanto Oittinen quanto Kumar e Malshe apontam o caráter ativo (compreensão ativa) da leitura feita pelo tradutor. Oittinen sugere que o tradutor é um tipo especial de leitor pelo fato de ele compartilhar sua leitura com o leitor da língua-meta. O tradutor é, de fato, um tipo especial de leitor 
não apenas por esse motivo, mas também porque ele se situa numa posição de interculturalidade em que nenhum de seus futuros leitores se situa.

De seu ponto privilegiado, o tradutor faz sua leitura ativa e constrói o texto traduzido. Mas de que modo é que sua leitura se reflete no texto produzido, como é que ele se apropria das palavras do autor? Para Kumar e Malshe as palavras do tradutor tornam-se 'bivocais passivas', isto é, o tradutor seria capaz de manter equilibradas em seu texto duas orientações semânticas, a da palavra do autor e a sua. Talvez uma breve revisão dos tipos de discurso propostos por Bakhtin, tendo em vista o texto traduzido, possa contribuir para o entendimento de como seria a relação de negociação de significados ou orientações semânticas na atividade tradutória.

Com relação aos tipos de discurso propostos por Bakhtin (cf., Bakhtin, 1969, p. 186-200), pode-se dizer que o texto traduzido nunca poderá ser um texto referencial direto e imediato, pois ele sempre vai partir do texto-fonte. $\mathrm{O}$ ideal de perfeccionismo que permeia em maior ou menor grau os três primeiros paradigmas do pensamento ocidental sobre tradução pretende que o texto traduzido seja semelhante ao discurso representado ou objetificado, no qual o texto-fonte é submetido a uma segunda orientação semântica, a do tradutor, mas sem sofrer nenhuma alteração de sentido e tom (cf. Bakhtin, 2005, p. 189). Esta segunda orientação deve apagar-se ao máximo para que o novo leitor tome a obra como se fosse um original. Mas, como é que a tradução poderia se constituir em discurso representado ou objetificado, uma vez que o discurso do texto-fonte não pode ser integralmente reconstituído tendo-se em vista um novo receptor, o leitor da tradução, que tem um perfil cultural diferente daquele leitor para o qual o "discurso objetificado" foi elaborado? O próprio tradutor, enquanto leitor, já alterou o contexto inicial do texto-fonte e isso já determinou a impossibilidade de uma simples "transmissão" que não alteraria o "sentido e o tom". O novo texto tem outro 'autor' e se dirige a outro leitor. O sentido não pode permanecer o mesmo e até o tom pode ter que se alterar para que o diálogo continue noutra cultura. Restam então as alternativas de discurso bivocal.

Segundo Bakhtin, no discurso bivocal do tipo passivo (estilização, narração, paródia), "o autor inclui no seu plano o discurso do outro voltado para as suas próprias intenções” (id., p. 193). Assim, se, como sugerem Kumar \& Malshe, a palavra da tradução é como a palavra bivocal passiva, isso equivale a afirmar que o tradutor é sempre capaz de impor a sua intenção ou a função que queira dar ao texto traduzido. No entanto, tal 'controle' por parte do tradutor se submete a variados 'graus' de acordo com diversos fatores, entre os quais: 1) a compatibilidade entre as línguas/culturas no sentido de permitir um maior ou menor re-agenciamento dos significados postos em jogo 
no texto-fonte, o que está estreitamente relacionado com a proximidade entre as culturas e línguas envolvidas, 2) o conhecimento e experiência do tradutor enquanto usuário de tais línguas/culturas, 3) a tarefa de tradução, i.e., o uso a ser dado ao texto traduzido, 4) a visão da cultura receptora e do tradutor em particular sobre o ato de traduzir, e 5) a atitude do tradutor frente ao textofonte: que tipo de palavra é a palavra do outro no texto-fonte para o tradutorleitor? Autoritária (e.g., religiosa, política, moral, etc)? Qual sua atitude para com essa palavra? Reconhecimento? Assimilação? Profanação?

Quanto a este último fator, é interessante observar que os exemplos oferecidos por Kumar \& Malshe indicam uma atitude de profundo respeito e diria mesmo de receio de profanar a palavra autoritária do texto-fonte (religioso, poético) de modo que muitas vezes a solução é manter a expressão na língua original para não calar as vozes que as enunciam e os múltiplos significados de tais palavras. Tal atitude pode ser alinhada com um dos lados do dilema entre estrangeirizar ou domesticar o texto-fonte apontado por Schleiermacher (1838/2001). Para Kumar e Malshe, "adotando-se os princípios de Bakhtin, pode-se argumentar que as duas tendências de domesticar e estrangeirizar estão relacionadas às forças centrípetas e centrífugas que atuam durante a tradução" (p. 123). Para esses autores, "ao possibilitar ao tradutor a incorporação de traços culturais de ambas as culturas, a palavra bivocal proporciona uma saída para o dilema de se ter que aderir a apenas um dos dois textos" (p. 122).

Kumar e Malshe reconhecem o fato de que "tanto o autor do texto-fonte quanto o leitor da cultura-meta podem ser trazidos para um espaço dialógico de interação em que o significado emerge a partir de um entendimento compartilhado" (ibid.). Eu diria mais - segundo uma perpectiva dialógica da tradução, todo texto traduzido é moldado não apenas pelo discurso do autor do texto-fonte mas também (e por vezes até mais) pelo discurso do leitor, que ele antecipa. Desse modo, podemos dizer que o texto traduzido é 'duplamente bivocal'. Tal hipótese justifica uma teorização da tradução não apenas em termos da palavra bivocal passiva, como o fazem Kumar e Malshe, mas também da palavra bivocal ativa ${ }^{7}$, visto que inúmeras são as possibilidades de enquadramento do texto-fonte a partir da interação dinâmica entre as vozes do tradutor, do autor, do leitor and língua-meta e outras vozes que ressoam nas culturas envolvidadas, tanto em traduções de textos distintos quanto numa dada tradução de um texto-fonte. Além disso, algumas dessas possibilidades de enquadramento são realizadas, inclusive, escapando ao controle consciente do tradutor. As categorias de "tradução tropológica" e os "tipos de ética" sugeridos por Robinson (1991) podem ser vistos como o início de tal exploração, mas esse tema fica para uma próxima ocasião.

\footnotetext{
${ }^{7}$ Por exemplo a intercalação da voz do tradutor no texto-fonte, como na "tradução irônica" sugerida por Robinson 1991, p. 171.
} 


\section{Conclusão}

Com o propósito de contribuir para a discussão sobre a perspectiva dialógica da tradução dentro dos Estudos da Tradução, este artigo tomou como referencial o mapeamento proposto por Robinson (1991) para o pensamento ocidental sobre tradução - os quatro paradigmas representados por Agostinho, Lutero, Goethe, e Buber/Bakhtin - definidos com relação a três princípios, o dualismo, o instrumentalismo e o perfeccionismo. Após um breve resumo dos três primeiros paradigmas, segundo Robinson já plenamente estabelecidos, a atenção se voltou para o quarto paradigma, o "dialógico", aproximando-se, via Robinson, de suas bases filosóficas através da leitura de alguns intérpretes das teorias de Buber e Bakhtin. Sobre a base desse quarto paradigma, foram introduzidas outras vozes que se pronunciaram sobre o tema "tradução e diálogo" - Pym (2002 e 2006), Oittinen (2000) e Kumar \& Malshe (2005). Em seguida, foram discutidas idéias apresentadas por esses autores, apontando-se algumas lacunas ou silêncios nesse diálogo - a ausência de Bakhtin na chamada "filosofia do diálogo" (Laygues, Pym) e a ausência de uma ênfase na idéia da "saturação ideológica" da linguagem, que segundo Robinson é o ponto-chave da teoria bakhtiniana. Por fim, em resposta à sugestão de Kumar \& Malshe de que apenas o discurso bivocal passivo é de interesse para o tradutor, foi sugerida a exploração do texto traduzido também a partir do conceito bakhtiniano de discurso bivocal ativo, uma vez que, segundo uma perspectiva dialógica da tradução, tal texto é moldado não apenas pelo discurso do autor do texto-fonte mas também pela atitude do tradutor frente ao texto-fonte, bem como pelo discurso do leitor, que ele antecipa.

Ao que tudo indica, o diálogo sobre "tradução e diálogo" dentro dos Estudos da Tradução está apenas começando e a constatação de uma mudança de paradigma, ou melhor, da introdução de um paradigma alternativo "dialógico" vai depender do desenrolar dessa conversa não apenas no âmbito da teoria mas também no da prática tradutória.

Ladjane Maria Farias de Soura Universidade Federal de Santa Catarina

University of Sydney ladjane.sonza@gmail.com 


\section{Referências}

BAKER, M; SALDANHA, G. (orgs.) Routledge Encyclopedia of Translation Studies. 2 ed. , Nova Iorque, Routledge, 2009.

BAKHTIN, M. Problemas da Poética de Dostoiévski. Tradução de Paulo Bezerra. 3a ed., Forense Universitária, 2005.

- Questões de Literatura e de Estética. A Teoria do Romance. São Paulo: UNESP/Hucitec, 1998.

(V. N. Volochínov). Marxismo e Filosofia da Linguagem: Problemas fundamentais do Método Sociológico na Ciência da Linguagem . São Paulo: Hucitec, 1981.

GOETHE, J. W. Três trechos sobre tradução. Tradução de Rosvitha Blume. In: HEIDERMANN, W. (org.) Clássicos da Teoria da Tradução. Antologia bilíngüe, Vol. I, Florianópolis: Núcleo de Tradução/UFSC. 2001, p. 16-23.

KUMAR, A.; MALSHE, M. Translation and Bakhtin's "Metalinguistics". Perspectives: Studies in Translatology, Volume 13, Número 2, Multilingual Matters, 2005, p. 115-122.

LAYGUES, A. Resenha do livro "Buber, Marcel, and Levinas". In A. Pym (ed), The Return to Ethics. Special issue of The Translator 7(2). 2001. p. 315-319.

. Pour une réaffirmation de l'« être-ensemble »par la traduction. Meta 51(4). 2006, 838-847.

. Pour une éthique du traducteur poéticien. Tese de Doutorado. University of Helsinki, 2007.

LUTERO, M. Carta aberta sobre a tradução. Tradução de Mauri Furlan. In: FURLAN, M. (org), Clássicos da Teoria da Tradução. Antologia bilíngüe, Vol. 4, Florianópolis: Núcleo de Tradução/UFSC. 2006, p. 94-115.

MARTINS, W. Bakhtin Revisitado. Resenha do livro "Entre a prosa e a poesia: Bakhtin e o formalismo russo", de Cristóvão Tezza. 2003. Disponível em http://www.cristovaotezza.com.br/critica/nao_ficcao/f_prosa/p_030802.ht m. Acesso em: 24/07/07. 
OITTINEN, R. Translating for Children. Garland Pub. Inc., New York/London, 2000 .

PYM, A. Translation technology as rupture in the philosophy of dialogue. Texto de uma palestra apresentada no VI Portsmouth Translation Conference, em outubro de 2006, sobre Tradução de Tecnologias e Culturas. Versão on-line 2007. Disponível em: http://www.tinet.org/ apym/online/translation/2007_dialogue_portsmouth.pdf. Acesso em 24/07/07.

- Translation Studies and Western Philosophy. Texto elaborado para publicação no The Companion to Translation Studies (Multilingual Matters), ed. Piotr Kuhiwczak and Karin Littau. 2002. Versão pré-impressão on-line disponível em: http://www.tinet.org/ apym/online/translation/philosophy.pdf . Acesso em 24/07/07.

ROBINSON, D. The Translator's Turn. Baltimore/London, Johns Hopkins University Press, 1991, 318 p.

SCHLEIERMACHER, Sobre os diferentes métodos de tradução. Tradução de Margarete von Mühlen Poll. In: FURLAN, M. (org), Clássicos da Teoria da Tradução. Antologia bilíngüe, Vol. 1, Florianópolis: Núcleo de Tradução/UFSC. 2006, p. 26-85.

VILELA, S. O. M.; BORGES, B. I. O diálogo na filosofia. Horizonte Científico, Revista eletrônica da Propp, Universidade Federal de Uberlândia, Minas Gerais, edição no 1, 2002. 